\title{
Mekanik alaşımlama yöntemi ile üretilen Al matrisli hibrit kompozit malzemenin farklı çözeltilerdeki korozyon davranışları
}

\author{
Doğan ŞİMŞEK* \\ Milli Savunma Üniversitesi Kara Astsubay MYO. Oto Tek. Böl., Balıkesir. \\ Geliş Tarihi (Received Date): 19.09.2021 \\ Kabul Tarihi (Accepted Date): 18.11.2021
}

$\ddot{O} \mathbf{z}$

Bu çalışmada, Mekanik Alaşımlama (MA) yöntemiyle üretilen alüminyum matrisli hibrit (in-situ $\mathrm{Al}_{4} \mathrm{C}_{3}$ ve ex-situ $\mathrm{Al}_{2} \mathrm{O}_{3}$ ) kompozit malzemenin farklı çözeltilerdeki korozyon davranışlart incelenmiştir. Alüminyum matrise \%2 grafit ve $\% 12 \mathrm{Al}_{2} \mathrm{O}_{3}$ ilave edilerek hazırlanan tozlar mekanik alaşımlanmıştır. Mekanik alaşımlanan hibrit kompozit tozlar $750 \mathrm{MPa}$ altında soğuk preslenmiş ve $600{ }^{\circ} \mathrm{C}$ sicaklıkta $120 \mathrm{dk}$ sinterlenmiştir. Üretilen AMK malzemelerin korozyon testleri \%3,5 $\mathrm{NaCl}$ ve 0,1 $\mathrm{M} \mathrm{H}_{2} \mathrm{SO}_{4}$ çözeltilerinde elektrokimyasal empedans spektroskopi (EIS) ve potansiyodinamik polarizasyon teknikleri kullanılarak yapılmıştır. Polarizasyon ölçümleri üç elektrot kurulumlu bir korozyon hücresinde ( $\mathrm{Ag} / \mathrm{AgCl}$ referans elektrotu, bir platin plaka ve karşıl elektrot) yapılmıştır. Mikroyapı çalışmalarında matrise ilave edilen $\mathrm{Al}_{2} \mathrm{O}_{3}$ takviyesinin tane sinırlarında kümelenme eğiliminde olduğu görülmüştür. Ayrıca matrise ilave edilen grafit'in yapıda tamamen çözünmediği iri grafit parçacıkları şekilde kaldı ̆̆ görülmüş̧̈̈r. XRD sonuçlarında yapıda oluşması beklenen $\mathrm{Al}_{4} \mathrm{C}_{3}$ fazının oluştuğu belirlenmiştir. Korozyon sonuçlarda hibrit kompozit malzemenin $\mathrm{NaCl}$ çözeltisi içerisinde daha düşük potansiyel ve daha düşük akım yoğunluğu elde edilmiştir. Empedans ölçümleri sonucunda $\mathrm{H}_{2} \mathrm{SO}_{4}$ çözeltisinde daha küçük bir yarım daire çapına sahip Nyquist eğrisi elde edilmiştir. Sonuçlarda NaCl çözeltisi içerisinde korozyon direncinin $\mathrm{H}_{2} \mathrm{SO}_{4}$ çözeltisinden daha iyi olduğu belirlenmiştir. Korozyon yüzeyi incelemelerinde baskın korozyon mekanizmasının çukurcuk korozyonu olduğu görülmüş̧ür.

Anahtar kelimeler: Hibrit kompozit, potansiyodinamik polarizasyon, empedans, korozyon.

\footnotetext{
* Doğan ŞiMŞEK, dsimsek@msu.edu.tr, https://orcid.org/0000-0002-5509-9314
} 


\title{
Corrosion behaviors in different solutions of hybrid composite produced by mechanical alloying method
}

\begin{abstract}
In this study, was investigated corrosion behavior in different solutions of aluminum matrix hybrid (in-situ $\mathrm{Al}_{4} \mathrm{C}_{3}$ and ex-situ $\mathrm{Al}_{2} \mathrm{O}_{3}$ ) composite material produced by Mechanical Alloying (MA) method. The powders prepared by adding 2\% graphite and $12 \% \mathrm{Al}_{2} \mathrm{O}_{3}$ to the aluminum matrix were mechanical alloyed. Mechanically alloyed hybrid composite powders were cold pressed under $750 \mathrm{MPa}$ and sintered at $600{ }^{\circ} \mathrm{C}$ for 120 min. Corrosion tests of the produced AMK materials were carried out in $3.5 \%$ $\mathrm{NaCl}$ and $0.1 \mathrm{M} \mathrm{H}_{2} \mathrm{SO}_{4}$ solutions using electrochemical impedance spectroscopy (EIS) and potentiodynamic polarization techniques. Polarization measurements were made in a corrosion cell with a three-electrode setup $(\mathrm{Ag} / \mathrm{AgCl}$ reference electrode, a platinum plate, and counter electrode). In the microstructure studies, it was observed that the Al2O3 reinforcement added to the matrix tended to cluster at the grain boundaries. In addition, it was observed that the graphite added to the matrix remained in the form of coarse graphite particles that did not completely dissolve in the structure. In the XRD results, it was observed that the $\mathrm{Al}_{4} \mathrm{C}_{3}$ phase expected to form in the structure was formed. In the results obtained, it was observed that the hibrit composite material had lower potential and lower current density in the $\mathrm{NaCl}$ solution. As a result of impedance measurements, a Nyquist curve with a smaller semicircle diameter was obtained in $\mathrm{H}_{2} \mathrm{SO}_{4}$ solution. The results showed that corrosion resistance in $\mathrm{NaCl}$ solution was better than in $\mathrm{H}_{2} \mathrm{SO}_{4}$ solution. Pitting corrosion was found to be the dominant corrosion mechanism in the corrosion surface examinations.
\end{abstract}

Keywords: Hybrid composite, potentiodynamic polarization, impedance, corrosion.

\section{Giriş}

Alüminyum matrisli kompozitler (AMK'ler) matris ve takviye elemanının iyi kobinasyonu ile yüksek özgül mukavemet, yüksek sertlik, düşük termal genleşme katsayısı, geliştirilmiş tribolojik özellikler ve düşük işlem sıcaklıkları gibi özelliklere sahip mühendislik malzemeleridir. AMK'ler yıllar boyunca araştırmacılar tarafından hızlı bir şekilde geliştirilmiş ve günümüzde de geliştirilmesine yönelik çalışmalar devam etmektedir. AMK'lerin sağladığı bu özellikler mükemmel korozyon direnci ve termal kararlılıkla birleştirildiğinde, AMK'ler otomotiv, havacılık, savunma, elektronik gibi endüstrilerde uygulama ve bileşenlerin tasarımı için mükemmel bir seçim haline getirmektedir [1,2]. AMK'lerde matris malzemesi olan Al ve alaşımları reaktiftir ve korozyon eğimi yüksektir. Ancak Al ve alaşımlarının en önemli avantajlarından bir tanesi de korozyon direncinin yüksek olmasıdır. Reaktif olan bir malzemenin korozyon direncinin yüksek olması şu şekilde açıklanır; Al ve alaşımlarının reaktif olması, bütün koşullarda oksijenle doğrudan oksidasyona yönelik doğal eğilimleri, yüzeylerinde koruyucu bir oksit film tabakası oluşturur. Bu oksit film, Al ve alaşımlarının korozyon direncinin yüksek olmasının nedenidir [3]. AMK'lerde uygun miktarlarda takviye ilave edilmesiyle Al ve alaşımlarına kıyasla mekanik ve tribolojik özelliklerinin arttığı bilinmektedir [4,5]. Ancak matrise ilave edilen ya da matriste oluşturulan ikinci faz partiküller bu özelliklerini geliştirirken korozyon hassasiyetini de artırmaktadır [6]. 
Metal matrisli kompozitlerde (MMK) takviye matris ara yüzü, yapıdaki kusurlar, intermetalikler, mekanik olarak hasarlı bölgeler, tane sınırları ve dislokasyonlar gibi fiziksel ve kimyasal hetorejenliğin varlığından dolayı korozyon reaksiyonun başlamasına neden olmaktadırlar [7,8]. AMK'lerin korozyon hassasiyeti genellikle çeşitli ortamlarda ya takviye ve matris arasında galvanik reaksiyonların oluşması ya da ara yüzeyde kusurların ve artık gerilmelerin varlığı nedeniyle artmaktadır [3]. Çukurlaşma özellikle klorür iyonları içeren çözeltilerde yüzey filminin kısmen bozulması ya da tamamen koruyucu olmadığı koşullar altında Al korozyonunun en yaygın biçimidir [3]. Şimşek [6] tarafından yapılan bir çalışmada, yaşlandırma işlemiyle yapıda oluşturulan ikincil faz partikül oranının artmasıyla (yaşlandırma süresinin artırılmasıyla) korozyon oranının arttığını belirtmiştir. Bunun nedeninin ise Al alaşımının yüzeyinde oluşan oksit tabakasının yapıda oluşturulan ikincil faz partikülleri nedeniyle sürekliliğinin bozulmasından kaynaklandığını belirtmiştir. De Salazar vd., [10] yaptıkları bir çalışmada isıl işlem ile yapıda oluşturulan ikincil faz çökeltileri ve nano alümina takviyesi etrafında çukurcuk korozyonunun geliştiğini belirtmişlerdir. Benzer şekilde $\% 10 \mathrm{Al}_{2} \mathrm{O}_{3}$ ilave edilen ve toz metalürjisi ile üretilen kompozit malzemelerin farklı alaşımlama sürelerinin korozyon davranışına etkisinin incelendiği bir çalışmada, artan alaşımlama süresinin korozyon direncini azalttı̆̆ belirtilmiştir. Bunun nedeninin artan alaşımlama süresiyle toz boyutunun küçülmesi ve bu nedenle tane sınırlarındaki artış, ayrıca deformasyon sertleşmesinden kaynaklanan sıkıştırılabilirliğin azalması nedeniyle gözenekli yapının oluşmasından kaynaklandığı belirtilmiştir [11]. Bununla birlikte Alaneme ve Olubambi [12] pirinç kabuğu külü (RHA) ve alümina takviyeli Al-Mg-Si matrisli hibrit kompozitlerin korozyon ve aşınma davranışlarını inceledikleri çalışmalarında tek takviyeli $\mathrm{Al}-\mathrm{Mg}-\mathrm{Si} / 10 \% \quad \mathrm{Al}_{2} \mathrm{O}_{3}$ kompozitin korozyon direncinin, \%3,5 NaCl çözeltisindeki hibrit kompozitlerden daha üstün olduğunu ve ağırlıkça \% RHA'daki artışla korozyon oranlarının arttığını rapor etmişlerdir. Benzer şekilde Erek vd., [13] in-situ $\mathrm{TiAl}_{3}$ ex-situ $\mathrm{B}_{4} \mathrm{C}$ takviyeli alüminyum matrisli hibrit kompozitlerin korozyon davranışlarını inceledikleri çalışmalarında, hibrit kompozitlerin artan takviye miktarıyla korozyon dirençlerinin azaldığını belirtmişlerdir. Bunun nedeninin matris ve takviye arasında oluşan arayüzey den kaynaklandığııı rapor etmişlerdir.

Yapılan bu çalışmada, otomotiv sektöründe yaygın olarak kullanılan kompozit malzemelerin bir çeşidi olan alüminyum matrisli hibrit kompozitlerin korozyon davranışı üzerine çalışılmıştır. Al matrise $\% 2$ grafit ve $\% 12 \quad \mathrm{Al}_{2} \mathrm{O}_{3}$ ilave edilerek mekanik alaşımlama yöntemiyle üretilmiştir. Üretilen ex-situ $\mathrm{Al}_{2} \mathrm{O}_{3}$ ve in-situ $\mathrm{Al}_{4} \mathrm{C}_{3}$ ile güçlendirilmiş alüminyum matrisli hibrit kompozit malzemenin farklı çözeltilerdeki korozyon davranışlarının belirlenmesi hedeflenmiştir.

\section{Malzeme ve metot}

Deneysel çalışmalarda kullanılan alüminyum (\%99,5 saflıkta) grafit ve $\mathrm{Al}_{2} \mathrm{O}_{3}$ SigmaAldrich firmasından temin edilmiştir. Matris malzemesi olarak kullanılan $<50 \mu \mathrm{m}$ boyutunda alüminyuma $\% 2$ grafit (\%hac.) ve $\% 12$ oranında ve toz boyutu $<10 \mu \mathrm{m}$ olan $\mathrm{Al}_{2} \mathrm{O}_{3}$ (\%hac.) takviye edilmiştir. Üretilen kompozit malzemelerin üretim parametreleri Tablo 1'de verilmiştir. 
Tablo 1. Üretilen kompozit malzemenin üretim parametreleri

\begin{tabular}{|c|c|}
\hline İşlem & Parametre \\
\hline \multicolumn{2}{|l|}{ Alaşımlama çalışmaları } \\
\hline Üretim yöntemi & Mekanik Alaşımlama (MA) \\
\hline Değirmen tipi & Planeter tip \\
\hline Öğ̈ütme hücresi & Paslanmaz çelik \\
\hline Bilye çap1 & $10 \mathrm{~mm}$ \\
\hline Bilye toz oranı & $10: 1$ \\
\hline İşlem Kontrol Kimyasalı & Etanol \%1 \\
\hline Alaşımlama süresi & $60 \mathrm{dk}$ \\
\hline \multicolumn{2}{|c|}{ Ön şekillendirme çalışmaları } \\
\hline Şekillendirme & Tek eksenli soğuk presleme \\
\hline Presleme basinc1 & $750 \mathrm{MPa}$ \\
\hline Numune ölçüsü & $\varnothing 10 \times 7 \mathrm{~mm}$ \\
\hline \multicolumn{2}{|l|}{ Sinterleme çalış̧maları } \\
\hline Sinterleme sicaklı̆ı 1 & $600^{\circ} \mathrm{C}$ \\
\hline Sinterleme ortam1 & Argon \\
\hline Sinterleme süresi & $120 \mathrm{dk}$ \\
\hline Soğuma & Firın ortamında oda sicaklığı \\
\hline \multicolumn{2}{|l|}{ Metalografi çalıșmaları } \\
\hline Metalografi işlemleri & $\begin{array}{l}\text { (400-1200) zımparalama ve } 1 \mu \mathrm{m} \text { elmas solüsyon } \\
\text { parlatma }\end{array}$ \\
\hline Dağlayıcı & $\begin{array}{l}\text { Keller's ( } 2 \mathrm{ml} \mathrm{HF}, 3 \mathrm{ml} \mathrm{HCI}, 20 \mathrm{ml} \mathrm{HNO}_{3}, 175 \\
\left.\text { ml H} \mathrm{H}_{2} \mathrm{O}\right)\end{array}$ \\
\hline Dağlama süresi & $10-15 \mathrm{~s}$ \\
\hline \multirow[t]{2}{*}{ Mikroyapı incelemeleri } & SEM+EDS (Carl Zeiss Ultra Plus Gemini Fesem) \\
\hline & XRD (Rigaku Ultima IV) \\
\hline
\end{tabular}

Korozyon testleri potansiyodinamik polarizasyon tekniği ile yapılmıştır. Korozyon testlerinde Iviumstat.XRe marka potansiyostat/galvonastat test cihazı kullanılmıştır. Polarizasyon ölçümleri üç elektrot kurulumlu bir korozyon hücresinde $(\mathrm{Ag} / \mathrm{AgCl}$ referans elektrotu, bir platin plaka ve karşıt elektrot) yapılmıştır. MA yöntemiyle üretilen $\mathrm{AMK} \% 3,5 \mathrm{NaCl}$ ve $0,1 \mathrm{M} \mathrm{H}_{2} \mathrm{SO}_{4}$ çözeltisinde elektrokimyasal empedans spektroskopi (EIS) ve potansiyodinamik polarizasyon teknikleri kullanılmıştır. Elektrokimyasal empedans spektroskopisi açı devre potansiyelinde $0,005-10000 \mathrm{~Hz}$ frekans aralığında ve $20 \mathrm{mV}$ genlik uygulanmıştır. Potansiyodinamik polarizasyon ölçümleri ise $\pm 0,75 \mathrm{~V}$ tarama aralığ ve $1 \mathrm{mV} / \mathrm{s}$ tarama hızında döngüsel polarizasyon ölçümü yapılmıştır. Korozyon testi sonrası korozyon yüzeyleri taramalı elektron mikroskobu (SEM) incelemeleri yapılmıştır.

\section{Bulgular ve tartışma}

Mekanik alaşımlama yöntemiyle $\% 2$ grafit ve $\% 12 \quad \mathrm{Al}_{2} \mathrm{O}_{3}$ ilave edilerek üretilen alüminyum matrisli hibrit kompozitlerin mikroyapı SEM görüntüsü ve EDS (alan) sonucu Şekil 1'de verilmiştir. 


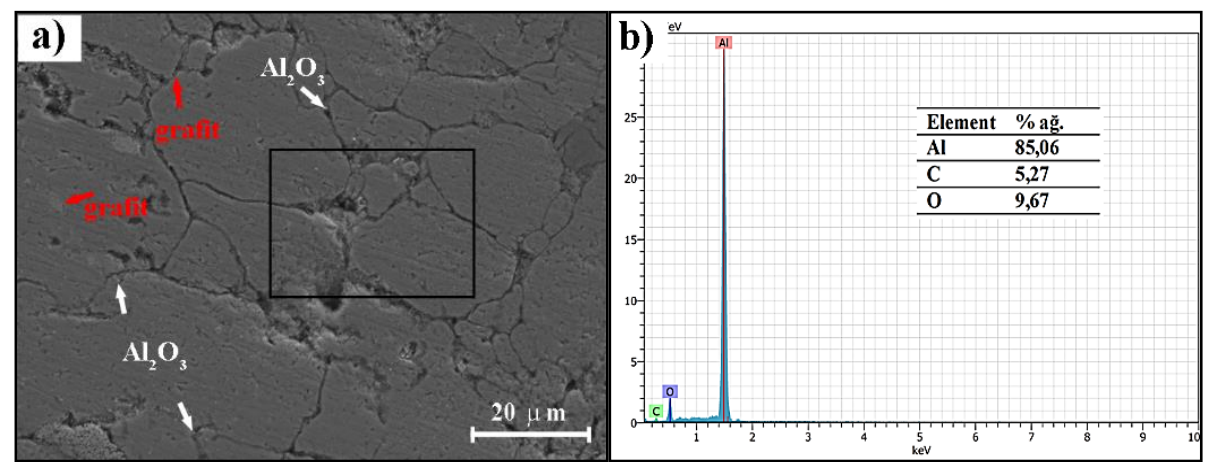

Şekil 1. MA yöntemiyle üretilen alüminyum matrisli hibrit kompozit malzemenin a) SEM görüntüsü ve b) EDS (alan) sonucu

Şekil 1'de verilen MA yöntemiyle üretilen hibrit kompozit malzemenin mikroyapı SEM görüntüsü incelendiğinde, farklı boyutlarda matris (Al) taneleri net olarak görülmektedir. MA yönteminde toz boyutu alaşımlama süresine bağlı değişmektedir. MA'nın ilk aşamalarında kaynaklanma sonucu artan toz boyutu, son aşamada deformasyon sertleşmesi ve kırılma sonucunda azalmaktadır [14]. Şekilde verilen SEM görüntüsünde ise iri tanelerle birlikte daha küçük tanelerinde olduğu görülmektedir. Bunun yanı sıra matrise ilave edilen grafitin yapıda çözünmeden iri grafit parçacı̆̆ 1 (açık gri alanlar) şeklinde kaldığı görülmektedir. Daha önce yapılan bir çalışmada, alaşıma ilave edilen grafitin boyutlarının çözünmede etkili olduğu küçük grafit parçacıklarının yapıda tamamen çözünürken, iri grafit parçacıkların ise çözünmeden parçacık şeklinde kaldığı bildirilmiştir [15]. Ayrıca kompozit malzemeye ilave edilen takviyenin $\left(\mathrm{Al}_{2} \mathrm{O}_{3}\right)$ tane sinırlarında konumlandığ 1 görülmektedir. Sajjadi vd., [16] yaptıkları çalışmalarında matris içerisinde artan nano $\mathrm{Al}_{2} \mathrm{O}_{3}$ miktarı ile kümelenme eğiliminin arttığını ve mekanik özelliklerinde ciddi bir azalma olduğunu belirtmişlerdir. Şekil 1.b'de verilen EDS sonucunda bir miktar oksitlenmenin olduğu anlaşılmaktadır. Oluşan bu oksitlenmenin MA sonrasında tozların ögütme/alaşımlama hücresinden alınması ve şekillendirme sırasında oluşabileceği, Şimşek vd. [17] tarafından yapılan bir çalışmada da rapor edilmiştir. $\% 12 \mathrm{Al}_{2} \mathrm{O}_{3}$ ve $\% 2$ grafit ilave edilerek üretilen alüminyum matrisli hibrit kompozit malzemenin XRD analizi sonucu Şekil 2'de verilmiştir.

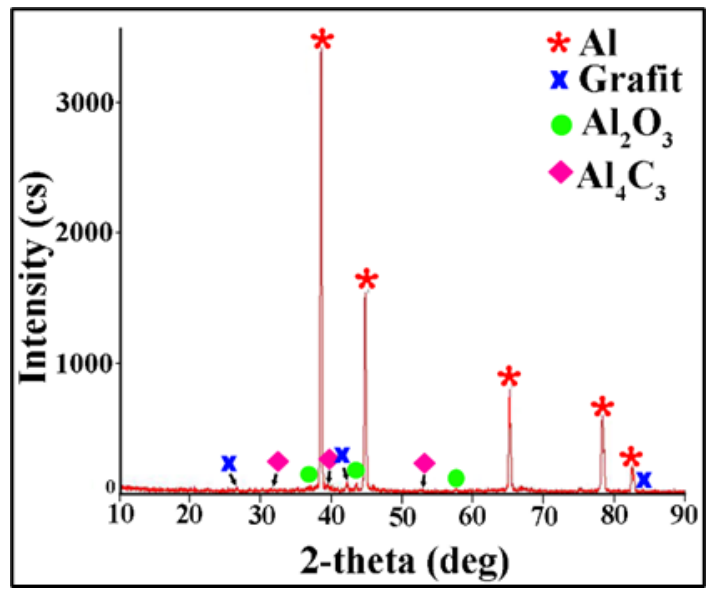

Şekil 2. MA yöntemiyle üretilen alüminyum matrisli hibrit kompozit malzemenin XRD sonucu 
Şekil 2'de verilen MA yöntemiyle Al matrise $\% 2 \mathrm{Gr}$ ve $\% 12 \mathrm{Al}_{2} \mathrm{O}_{3}$ fazı ilave edilerek üretilen hibrit kompozit malzemenin XRD sonucu incelendiğinde, matris malzemesinin (Al) (Kart numaras1: 9011602) ve grafit (Kart numaras1: 00-056-0159) olduğu görülmektedir. Benzer şekilde matrise ilave edilen grafitin yapıda çözünerek oluşması beklenen $\mathrm{Al}_{4} \mathrm{C}_{3}$ (Kart numarası: 00-035-0799) fazının da oluştuğu görülmektedir. Ancak XRD sonuçlarında oluşan bu bileşik $\left(\mathrm{Al}_{4} \mathrm{C}_{3}\right)$ düşük pik yoğunluğu (pik şiddeti) nedeniyle net olarak görülmektedir. $\mathrm{Bu}$ durum iki şekilde açıklanabilir. Birincisi yapıda oluşan bileşiğin nano boyutlarda oluşmasıdır. Bostan vd. [18] tarafından yapılan bir çalışmada, $\mathrm{Al}-\mathrm{C}$ alaşım sisteminde yapıda nano $\mathrm{Al}_{4} \mathrm{C}_{3}$ fazının oluştuğu rapor edilmiştir. Ayrıca XRD'nin düşük tarama aralığı bu fazın görülememesinin diğer bir nedeni olarak söylenebilir. Daha önce yapılan bir çalışmada benzer sonuçların elde edildiği bildirilmiştir [19]. MA yöntemiyle üretilen alüminyum matrisli hibrit kompozitlerin farklı çözeltilerde a) potansiyodinamik polarizasyon tafel eğrileri, b) elektrokimyasal empedans spektroskopisi (Nyquist eğrileri) Şekil 3 'te verilmiştir.

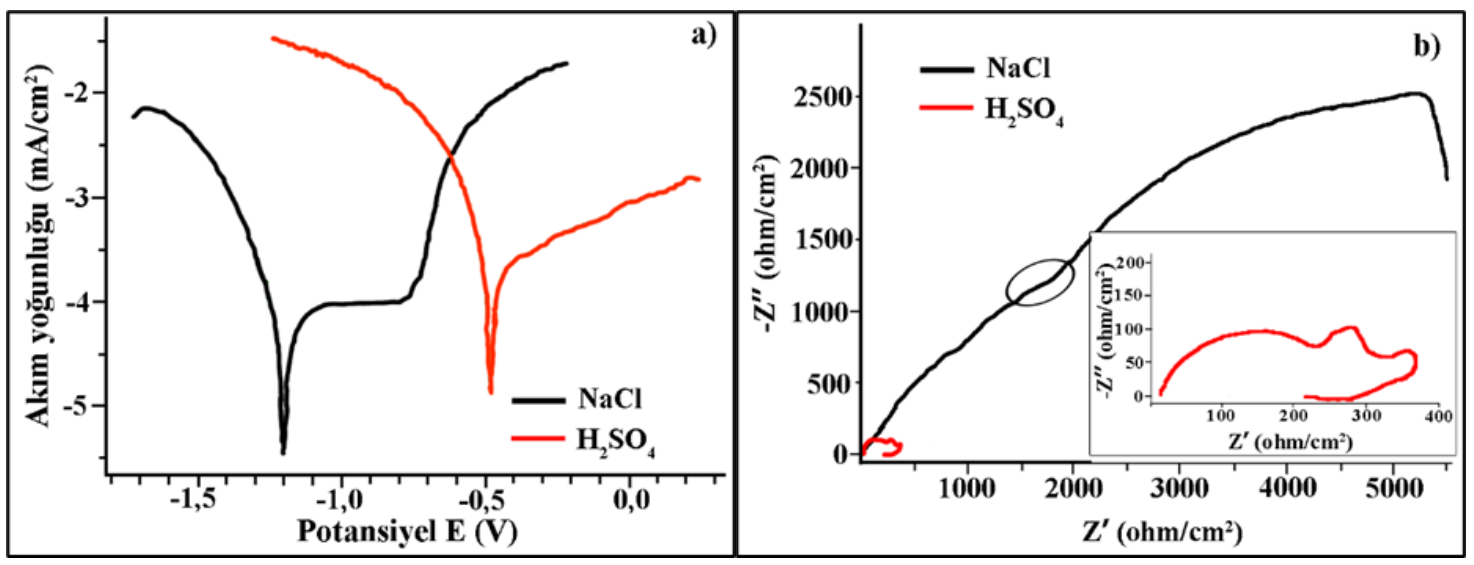

Şekil 3. MA yöntemiyle üretilen alüminyum matrisli hibrit kompozit malzemenin farklı çözeltilerde a) potansiyodinamik polarizasyon tafel eğrileri, b) elektrokimyasal empedans spektroskopisi (Nyquist eğrileri)

Şekil 3.a'da verilen MA yöntemiyle üretilen alüminyum matrisli hibrit kompozit malzemenin farklı çözeltilerde elde edilen tafel eğrileri incelendiğinde, üretilen hibrit kompozitin $\mathrm{NaCl}$ çözeltisinde daha düşük potansiyel değerine sahip olduğu görülmektedir. Benzer şekilde $\mathrm{NaCl}$ çözeltisi içerisinde elde edilen akım yoğunluğunun da $\mathrm{H}_{2} \mathrm{SO}_{4}$ çözeltisinde elde edilen akım yoğunluğundan düşük olduğu anlaşılmaktadır. Üretilen hibrit kompozit malzemenin korozyon direncinin $\mathrm{H}_{2} \mathrm{SO}_{4}$ çözeltisine göre $\mathrm{NaCl}$ çözeltisi içerisinde daha iyi olduğu anlaşılmaktadır. Tafel eğrilerinden elde edilen korozyon akımı belirleyici bir parametredir. Faraday bağıntısına göre akım yoğunluğu korozyon hızının belirlenmesinde kullanılan parametrelerden biridir. $\mathrm{Bu}$ bağıntıda korozyon reaksiyonu devam ederken malzeme üzerinden geçen akım miktarıyla, malzemeden çözünen madde miktarı arasında doğru orantı bulunmaktadır. Faraday bağıntısına göre malzemenin korozyonu sırasında akım yoğunluğunun düşük olması malzemenin korozyon direncinin yüksek olmasını göstermektedir. Tablo 2'de verilen tafel eğrilerinden elde edilen korozyon parametrelerinde, $\mathrm{NaCl}$ çözeltisinde Ekor değerinin $-1,2013 \mathrm{~V}$, Ikor değerinin $-1,61 \times 10^{-2} \mathrm{~A} / \mathrm{cm}^{2}$ olduğu görülmektedir. Ayrıca yüksek potansiyel direnci $(\operatorname{Rp} 902,2 \Omega)$ ve düşük korozyon oranı $(0,1773 \mathrm{~mm} / \mathrm{y})$ elde edilmiştir. Benzer şekilde $\mathrm{H}_{2} \mathrm{SO}_{4}$ çözeltisinde ise Ekor değerinin $-0,481 \mathrm{~V}$, Ikor değeri ise $-6,82 \times 10^{-5} \mathrm{~A} / \mathrm{cm}^{2}$ olduğu görülmektedir. Bu çözeltide ise düşük potansiyel direnci $(\operatorname{Rp} 237,3 \Omega)$ ve yüksek korozyon oranı $(0,751 \mathrm{~mm} / \mathrm{y})$ elde edilmiştir. Şekilde verilen 
tafel eğrilerinde $\mathrm{NaCl}$ çözeltisinde anodik dalda akım yoğunluğunun belirli bir zaman aralığında sabit kaldığ 1 ve bu zamanın sonunda ani bir akım yoğunluğu artışının olduğu görülmektedir. Anodik dalın belirli bir bölgedeki sabit hareketi numune yüzeyinde oluşan oksit tabakasını temsil etmektedir. Daha sonra görülen akım yoğunluğundaki ani artış ise numune yüzeyinde oluşan oksit tabakasında hasar oluştuğunu gösterir. Oluşan bu hasar bölgesinde ise korozyon hızı ilerler ve özellikle bu hasar oluşan bölgelerde çukurcuk ve çatlak korozyonu oluşmaktadır [9]. Ayrıca yüzeyde oluşan oksit tabakasının matrise ilave edilen takviye malzemesi ile sürekliliğinin bozulması AMK'lerin korozyon hassasiyetini artırmaktadır [20].

Tablo 2. Potansiyodinamik polarizasyon tafel eğrileri korozyon verileri

\begin{tabular}{|l|c|c|}
\hline & NaCl & $\mathbf{H}_{2} \mathrm{SO}_{4}$ \\
\hline $\mathbf{E}_{\text {kor }}(\mathbf{V})$ & $-1,2013$ & $-0,4813$ \\
\hline $\mathbf{I}_{\text {kor }}\left(\mathbf{A} / \mathbf{c m}^{\mathbf{2}}\right)$ & $-1,61 * 10^{-2}$ & $-6,82^{*} 10^{-5}$ \\
\hline Rp (ohm) & 902,2 & 237,3 \\
\hline K. Oranı (mm/y) & 0,1773 & 0,7519 \\
\hline
\end{tabular}

Şekil 3.b'de verilen MA yöntemiyle üretilen alüminyum matrisli hibrit kompozit malzemenin farklı çözeltilerde elde edilen elektrokimyasal empedans spektroskopisi (EIS) (Nyquist eğrileri) incelendiğinde, iki farklı çözeltide de farklı eğrilerin olduğu görülmektedir. Nyquist eğrilerinde kapasitif luplar korozyon reaksiyonunda yük transferi ve yüzeyde oluşan koruyucu film tabakası ile ilişkilidir. $\mathrm{H}_{2} \mathrm{SO}_{4}$ çözeltisi ve $\mathrm{NaCl}$ çözeltisinde elde edilen Nyquist eğrisi karşılaştırıldığında, $\mathrm{H}_{2} \mathrm{SO}_{4}$ çözeltisinde daha küçük bir yarım daire çapına sahip olduğu görülmektedir. EIS ölçümlerinden elde edilen kapasitif eğri altında kalan alan korozyon direncinin bir göstergesidir. Geniş alana sahip Nyquist eğrileri yüksek korozyon direncini gösterir [21]. Ayrica $\mathrm{H}_{2} \mathrm{SO}_{4}$ çözeltisinde elde edilen eğride düşük frekans aralığında endüktif bir döngü görülmektedir. EIS sonuçlarında düşük frekans aralığında oluşan bu endüktif döngü, yüzeyin kısmen ya da tamamen aktif olduğunu gösterir [22]. Yüzeyin kısmen ya da tamamen aktif olması korozyon direncini azaltmaktadır. $\mathrm{NaCl}$ çözeltisinde elde edilen eğri incelendiğinde yüksek frekans aralığında (yaklaşık olarak $1500 \mathrm{ohm}$ karşılık gelen bölgede) küçükte olsa kapasitif bir lupun (işaretli bölge) oluştuğu görülmektedir. Bu durum yüzeyde oluşan koruyucu oksit tabakasında kısmen hasarın oluştuğu ve oluşan bu hasar bölgesinde korozyon reaksiyonunun gerçekleştiği anlamı taşımaktadır. EIS ölçümlerinde oluşan bu küçük luplar korozyon ürünlerinin numune yüzeyine tutunamaması ve yüzeyden ayrılmasından kaynaklandığı belirtilmiştir [17]. Huanhuan vd. [23] yaptıkları bir çalışmada, EIS sonuçlarında kapanmayan iki lupun oluşmasının nedenini, malzemenin yüzeyinde oluşan anodik koruyucu filmin zarar görmesinden dolayı olduğunu belirtmişlerdir. MA yöntemiyle üretilen alüminyum matrisli hibrit kompozit malzemenin farklı çözeltilerde elde edilen korozyon yüzeyi SEM görüntüleri Şekil 4'te verilmiştir. 


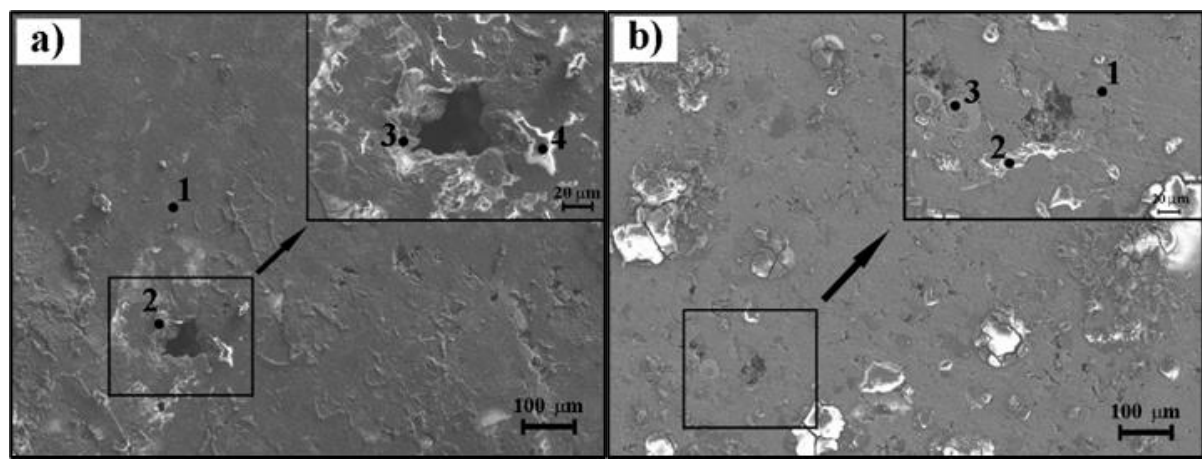

Şekil 4. MA yöntemiyle üretilen alüminyum matrisli hibrit kompozit malzemenin farklı çözeltilerde elde edilen korozyon yüzeyi SEM görüntüleri a) $\mathrm{NaCl}$, b) $\mathrm{H}_{2} \mathrm{SO}_{4}$

Şekil 4'te verilen MA yöntemiyle üretilen alüminyum matrisli hibrit kompozit malzemenin farklı çözeltilerde elde edilen korozyon yüzeyi SEM görüntüleri incelendiğinde, her iki çözeltide de baskın korozyon mekanizmasının bölgesel çukurcuk korozyonu olduğu anlaşılmaktadır. $\mathrm{NaCl}$ çözeltisinde oluşan çukurcuğun $\mathrm{H}_{2} \mathrm{SO}_{4}$ çözeltisinde elde edilen çukurcuklarla kıyaslandiğında daha geniş olduğu anlaş1lmaktadır. Ancak $\mathrm{H}_{2} \mathrm{SO}_{4}$ çözeltisinde elde edilen korozyon yüzeyi SEM görüntüsü incelendiğinde oluşan çukurcukların korozyon yüzeylerinde daha fazla olduğu görülmektedir. Korozyon yüzeyi SEM görüntüleri hem tafel eğrilerinde hem de EIS ölçümlerinde elde edilen sonuçları desteklemektedir. Tafel eğrilerinde elde edilen yüksek akım yoğunluğu ve EIS ölçümlerinden elde edilen Nyquist eğrilerinde $\mathrm{H}_{2} \mathrm{SO}_{4}$ çözeltisinde korozyon oranının yüksek olduğu anlaşılmaktadır. $\mathrm{H}_{2} \mathrm{SO}_{4}$ çözeltisinde elde edilen Nyquist eğrisinde düşük frekans hızlarında endüktif döngü elde edilmiştir. $\mathrm{Bu}$ endüktif döngü korozyon yüzeyinin kısmen ya da tamamen aktif olduğunu göstermektedir. Tablo 3'te verilen EDS sonuçları bu durumu net bir şekilde açıklamaktadır. $\mathrm{NaCl}$ çözeltisinde elde edilen sonuçlarda matris malzemesinin yüzeyinde (1 numaralı konum) alüminyum oksit varlığı EDS sonuçlarından görülürken, $\mathrm{H}_{2} \mathrm{SO}_{4}$ çözeltisinde ise (1 numaralı konum) yüzeyin çok yüksek miktarda $\mathrm{Al}$ olduğunu göstermektedir. Elde edilen EDS sonuçlarından $\mathrm{H}_{2} \mathrm{SO}_{4}$ çözeltisinde malzemenin yüzeyinde koruyucu oksit tabakasının oluşmadığı/oluşamadığını ve yüzeyin aktif olduğunu göstermektedir.

Tablo 3. Üretilen hibrit kompozitlerin korozyon yüzeyi EDS sonuçları

\begin{tabular}{|l|c|c|c|c|c|}
\hline & Konum & $\mathbf{1}$ & $\mathbf{2}$ & $\mathbf{3}$ & $\mathbf{4}$ \\
\hline \multirow{4}{*}{ NaCl çözeltisi } & $\mathrm{Al}$ & $\mathbf{5 7 , 4 7}$ & 1,96 & 35,49 & 34,59 \\
\cline { 2 - 6 } & $\mathrm{C}$ & 3,38 & 0,10 & 3,77 & 3,03 \\
\cline { 2 - 6 } & $\mathrm{O}$ & $\mathbf{3 8 , 5 3}$ & 97,73 & 59,81 & 62,30 \\
\cline { 2 - 6 } & $\mathrm{Cl}$ & 0,44 & 0,00 & 0,41 & 0,00 \\
\cline { 2 - 6 } & $\mathrm{Na}$ & 0,18 & 0,14 & 0,52 & 0,09 \\
\hline \multirow{3}{*}{ H2SO4 çözeltisi $^{\mathrm{Al}}$} & $\mathbf{9 4 , 7 7}$ & 24,18 & 0,07 & \\
\cline { 2 - 6 } & $\mathrm{C}$ & 3,26 & 6,25 & 99,68 & \\
\cline { 2 - 6 } & $\mathrm{O}$ & $\mathbf{1 , 9 3}$ & 64,51 & 0,21 & \\
\cline { 2 - 6 } & $\mathrm{S}$ & 0,04 & 5,06 & 0,04 & \\
\hline
\end{tabular}

Daha önce yapılan bir çalışmada, alüminyum matrisli hibrit kompozitlerin korozyon testleri sonrasında elde edilen korozyon yüzeylerinde bölgesel korozyonun baskın 
korozyon mekanizması olduğunu bildirmişlerdir [24]. MMK'lerde takviye matris ara yüzü, yapıdaki kusurlar, intermetalikler, mekanik olarak hasarlı bölgeler, tane sınırları ve dislokasyonlar gibi fiziksel ve kimyasal hetorejenliğin varlığından dolayı korozyon reaksiyonun başlayabileceği yerlerde baskın korozyon mekanizmasının bölgesel korozyon olarak tanımlanmaktadır [7,8]. Şekilde verilen SEM görüntüleri incelendiğinde (özellikle $\mathrm{H}_{2} \mathrm{SO}_{4}$ çözeltisinde) oluşan çukurcukların başlangıcının tane sınırları üzerinde olduğu anlaşılmaktadır. Bu durum toz metalurjisi yöntemi ile üretilen malzemelerde tam doluluk oranına ulaşılamaması nedeniyle yapıdaki gözeneklilik ve tane sınırlarına konumlanan takviye malzemesinden kaynaklanmaktadır. Daha önce yapılan bazı çalışmalarda da benzer sonuçlar elde edilmiştir [6, 24]. Ayrıca yapıda çözünmeyen grafit parçacıklarının etrafinda çukurcuk korozyonunun oluştuğu Şimşek [25] tarafından yapılan bir çalışmada belirtilmiştir.

\section{Sonuçlar}

Mekanik alaşımlama yöntemiyle üretilen $\mathrm{Al}$ matrisli grafit ve $\mathrm{Al}_{2} \mathrm{O}_{3}$ takviyeli hibrit kompozit malzemelerin farklı çözeltilerdeki korozyon davranışlarının incelendiği bu çalışmada, elde edilen sonuçlar aşağıda sıralanmıştır.

Mekanik alaşımlama yöntemiyle üretilen hibrit kompozit malzemenin mikroyapı incelemeleri sonucunda takviye malzemesi tane sınırlarına konumlanmıştır. Ayrıca matrise ilave edilen grafitin tamamen çözünmediği ve grafit parçacıkları şeklinde kaldığ görülmüştür.

Mekanik alaşımlama yöntemiyle üretilen hibrit kompozit malzemenin XRD sonucunda, yapıda in-situ oluşması beklenen $\mathrm{Al}_{4} \mathrm{C}_{3}$ bileşiğinin oluştuğu görülmüştür.

Mekanik alaşımlama yöntemiyle üretilen hibrit kompozit malzemenin farklı çözeltilerdeki korozyon sonuçlarında, $\mathrm{H}_{2} \mathrm{SO}_{4}$ çözeltisine kıyasla, $\mathrm{NaCl}$ çözeltisinde daha iyi korozyon direncine sahip olduğu görülmüştür. Korozyon mekanizmasının bölgesel çukurcuk korozyonu olduğu anlaşılmıştır. Çukurcuk korozyonunun daha çok tane sınırlarında olduğu görülmüştür.

\section{Kaynaklar}

[1] Alaneme, K.K., Anabaranze, Y.O., ve Oke, S.R., Softening Resistance, Dimensional Stability and Corrosion Behaviour of Alumina and Rice Husk Ash Reinforced Aluminium Matrix Composites, Subjected to Thermal Cycling. Tribology in Industry, 37, 2, 204-214 (2015).

[2] Kala, H., Mer, K.K.S., ve Kumar, S., A review on mechanical and tribological behaviors of stir cast aluminum matrix composites., Procedia Materials Science, 6, 1951-1960, (2014).

[3] McCafferty, E. Sequence of steps in the pitting of aluminum by chloride ions, Corrosion Science, 45, 7, 1421-1438, (2003).

[4] Simsek, D., Simsek, I., ve Ozyurek, D., Relationship between Al2O3 content and wear behavior of $\mathrm{Al}+2 \%$ graphite matrix composites, Science and Engineering of Composite Materials, 27, 1, 177-185, (2019). 
[5] Al-Salihi, H.A., Mahmood, A.A., ve Alalkawi, H.J., Mechanical and wear behavior of AA7075 aluminum matrix composites reinforced by $\mathrm{Al} 2 \mathrm{O} 3$ nanoparticles, Nanocomposites, 5, 3, 67-73, (2019).

[6] Şimşek, I. Investigation of the effect of second phase precipitates on the corrosion and electrical conductivity of 7075 aluminum alloys, Anti-Corrosion Methods and Materials, 66, 5, 683-688, (2019).

[7] Dolata, A.J., Dyzia, M., ve Walke, W. Influence of particles type and shape on the corrosion resistance of aluminium hybrid composites, In Solid State Phenomena, 191, 81-87, (2012).

[8] Alaneme, K.K. Corrosion behaviour of heat-treated Al-6063/SiCp composites immersed in $5 \mathrm{wt} \% \mathrm{NaCl}$ solution, Leonardo Journal of Science, 18, 18, 5564, (2011).

[9] Bobic, B., Mitrovic, S., Babic, M., ve Bobic, I. Corrosion of metal-matrix composites with aluminium alloy substrate, Tribology in Industry, 32, 1, 3, (2010).

[10] De Salazar, J.M.G., Urena, A., Manzanedo, S., ve Barrena, M. I., Corrosion behaviour of AA6061 and AA7005 reinforced with $\mathrm{Al}_{2} \mathrm{O}_{3}$ particles in aerated $3.5 \%$ chloride solutions: potentiodynamic measurements and microstructure evaluation, Corrosion Science, 41, 3, 529-545, (1998).

[11] Karacif, K., Karabulut, H., ve Çıtak, R., $\mathrm{Al}_{2} \mathrm{O}_{3}$ Takviyeli alüminyum esaslı kompozit malzemelerde mekanik alaşımlama süresinin korozyon davranışına etkilerinin incelenmesi, International Journal of Engineering Research and Development, 11, 2, 576-583, (2019).

[12] Alaneme, K. K., ve Olubambi, P. A., Corrosion and wear behaviour of rice husk ash-Alumina reinforced Al-Mg-Si alloy matrix hybrid composites. Journal of Materials Research and Technology, 2, 2, 188-194, (2013).

[13] Erek, H. B., Özyürek, D., ve Asan, A., Corrosion behaviour and electrical conductivity of reinforced $\mathrm{TiAl}_{3}$ and $\mathrm{B}_{4} \mathrm{C}$ hybrid aluminium composites. Acta Physica Polonica A, 131, 156-158, (2017).

[14] Özyürek, D., ve Tekeli, S., An investigation on wear resistance of SiCpreinforced aluminium composites produced by mechanical alloying method, Science and Engineering of Composite Materials, 17,1, 31-38, (2010).

[15] Chu, H. S., Liu, K. S., ve Yeh, J. W., Damping behavior of in situ Al(graphite, Al4C3) composites produced by reciprocating extrusion, Journal of Materials Research, 16, 5, 1372-1380, (2001).

[16] Sajjadi, S.A., Parizi, M.T., Ezatpour, H.R., ve Sedghi, A., Fabrication of A356 composite reinforced with micro and nano $\mathrm{Al}_{2} \mathrm{O}_{3}$ particles by a developed compocasting method and study of its properties, Journal of Alloys and Compounds, 511, 1, 226-231, (2012).

[17] Şimşek, İ., Şimşek, D., ve Özyürek, D., B ${ }_{4} \mathrm{C}$ Takviyeli alüminyum matris kompozitlerin farklı çözeltilerdeki korozyon davranışları, Journal of Boron, 5, 1, 23-28, (2019).

[18] Bostan, B., Özdemir, A. T., ve Kalkanli, A., Microstructure characteristics in Al-C system after mechanical alloying and high temperature treatment, Powder Metallurgy, 47, 1, 37-42, (2004).

[19] Şimşek, İ., Şimşek, D., ve Özyürek, D., The effect of different sliding speeds on wear behavior of $\mathrm{ZrO}_{2}$ reinforcement aluminium matrix composite materials, International Advanced Researches and Engineering Journal, 4, 1, 1-7, (2020). 
[20] Dobrzański, L. A., Włodarczyk, A., ve Adamiak, M., Structure, properties and corrosion resistance of PM composite materials based on EN AW-2124 aluminum alloy reinforced with the $\mathrm{Al}_{2} \mathrm{O}_{3}$ ceramic particles, Journal of Materials Processing Technology, 162, 27-32, (2005).

[21] Katkar, V.A., Gunasekaran, G., Rao, A.G., ve Koli, P.M., Effect of the reinforced boron carbide particulate content of AA6061 alloy on formation of the passive film in seawater, Corrosion Science, 53, 9, 2700-2712, (2011).

[22] Li, L.F., Daerden, M., Caenen, P., ve Celis, J.P., Electrochemical behavior of hot-rolled 304 stainless steel during chemical pickling in $\mathrm{HCl}$-based electrolytes, Journal of the Electrochemical Society, 153, 5, B145-B150, (2006).

[23] Huanhuan, S., Hui, W., ve Fanling, M., Study of corrosion protection of the composite films on A356 aluminum alloy, Journal of Rare Earths, 29, 10, 991-996, (2011).

[24] Alaneme, K.K., Olubambi, P.A., Afolabi, A.S., ve Bodurin, M.O., Corrosion and tribological studies of bamboo leaf ash and alumina reinforced $\mathrm{Al}-\mathrm{Mg}-\mathrm{Si}$ alloy matrix hybrid composites in chloride medium, International Journal of Electrochemical Science, 9, 10, 5663-5674, (2014).

[25] Şimşek, İ. Investigation of Corrosion Behaviors of Al-B4C-reinforced Composite Materials in Different Antifreeze Solutions, Protection of Metals and Physical Chemistry of Surfaces, 57, 3, 565-569, (2021). 